\title{
Article \\ Heavy Metals in Urban Street Dust: Health Risk Assessment (Lublin City, E Poland)
}

\author{
Wojciech Zgłobicki * (D) and Małgorzata Telecka \\ Institute of Earth and Environmental Sciences, Maria Curie-Skłodowska University, Kraśnicka Av. 2d, \\ 20-718 Lublin, Poland; m.telecka@umcs.pl \\ * Correspondence: wojciech.zglobicki@umcs.pl; Tel.: +48-81-537-6884
}

Citation: Zgłobicki, W.; Telecka, M Heavy Metals in Urban Street Dust: Health Risk Assessment (Lublin City, E Poland). Appl. Sci. 2021, 11, 4092. https://doi.org/10.3390/app11094092

Received: 14 April 2021

Accepted: 26 April 2021

Published: 30 April 2021

Publisher's Note: MDPI stays neutral with regard to jurisdictional claims in published maps and institutional affiliations.

Copyright: (c) 2021 by the authors. Licensee MDPI, Basel, Switzerland. This article is an open access article distributed under the terms and conditions of the Creative Commons Attribution (CC BY) license (https:// creativecommons.org/licenses/by/ $4.0 /)$.
Featured Application: Determining the intensity and spatial pattern of health risk caused by heavy metals in street dust helps in the proper management of the city's environment.

\begin{abstract}
Various pollutants, including heavy metals, present in street dust can pose a threat to the health of city dwellers. So far, studies on levels of this threat have been carried out mainly in large cities, characterised by considerable road traffic and industrial activity. This paper assesses the levels of hazard index and cancer risk for $\mathrm{Cd}, \mathrm{Cr}, \mathrm{Cu}, \mathrm{Ni}, \mathrm{Pb}$ and $\mathrm{Zn}$ contained in street dust collected in 2013 and 2018 at 62 points located in different parts of a small/medium-sized city (Lublin, E Poland). Heavy metals contents were analysed by means of XRF spectrometry (in the fraction $<63 \mu \mathrm{m})$. Despite the fact that the concentrations of some elements ( $\mathrm{Zn}, \mathrm{Cd}$ and $\mathrm{Cu}$ ) in street dust are 6-7 times higher than the geochemical background, this does not pose a risk of non-carcinogenic effects. The average hazard index (HI) for the individual elements reaches very low levels $(<0.01)$. Cancer risk (CR) for adults is below the less strict limit of $10^{-4}$, and in the case of $\mathrm{Pb}$, it is even lower than values of the order of $10^{-6}$, whereas for children, CR levels exceed the standards and are of the order of $10^{-4}$, except for $\mathrm{Pb}$. For all metals except $\mathrm{Cr}$, the health risk was higher in 2013 than in 2018.
\end{abstract}

Keywords: geochemistry; public health; urban environment

\section{Introduction}

Dust accumulating on the surface of roads and streets (street dust and road dust) arouses great interest in researchers owing to the pollutants it contains, mainly heavy metals that may pose a threat to human health [1-7]. Street dust is composed of mineral and organic particles of varying origin, including industrial sources and those related to vehicle traffic. The main components of the dust are quartz and feldspar, but it also contains heavy metals such as $\mathrm{Cd}, \mathrm{Cu}, \mathrm{Pb}$ and $\mathrm{Zn}$. They originate from the exhaust fumes of car engines and the abrasion of various vehicle parts (tyres and brake discs), road pavements, or the overhead lines (used by trams, trolleybuses and trains). Heavy metals can also originate from operating fluids released from vehicles onto the street surface $[1,3,8,9]$. Ongoing studies indicate increased content of trace elements in street dust in urban areas (e.g., [10-14]). Such increased concentrations are observed particularly in the case of lead, cadmium, copper, chromium, and nickel. Studies focus on big cities characterized by a high intensity of motor vehicle traffic and the presence of industrial emitters [15-18].

The geochemistry of street dust provides a wealth of information about the state of the urban environment. At the same time, street dust can be a health hazard due to its re-suspension. It becomes a component of ground level atmosphere, in the living zone of humans, plants and animals. Therefore, it can penetrate human organisms relatively easily and thus lead to the development of pathogenic processes [6,19-21]. The health risk assessments combine the volume of environmental pollution with the probability of its toxic effect on people. Hazard index (HI) and cancer risk (CR) are the most frequently used 
indices for a quantitative description of non-carcinogenic and carcinogenic risks related to human exposure to heavy metals contained in street dust [22-30].

The objective of this study was to assess the spatial and temporal variation in health risk posed by heavy metals contained in street dust in the area of Lublin. The content of $\mathrm{Cd}, \mathrm{Cr}, \mathrm{Cu}, \mathrm{Ni}, \mathrm{Pb}$ and $\mathrm{Zn}$, commonly regarded as the most serious sources of pollution in urban areas, was analysed $[6,31,32]$. The heavy metal content in street dust in Lublin had already been studied [32,33]. There are no studies determining the spatial distribution of health risk within the city of Lublin. So far research on this problem has been conducted mainly in cities with a high impact of industrial emissions, which currently do not seem to be a very important source of pollution in Lublin. Our research fills the gap related to the health risks caused by heavy metals in street dust in medium-sized cities without an intensive industrial impact.

\section{Materials and Methods}

Lublin is located in the north-western part of the Lublin Upland, E Poland $\left(51^{\circ} 08^{\prime} 23.31^{\prime \prime}-\right.$ $51^{\circ} 17^{\prime} 47.61^{\prime \prime} \mathrm{N}, 22^{\circ} 27^{\prime} 15.41^{\prime \prime}-22^{\circ} 40^{\prime} 24.75^{\prime \prime} \mathrm{E}$ ). The city covers an area of about $150 \mathrm{~km}^{2}$ and is inhabited by about 350,000 people. In the second half of the twentieth century, several major industrial plants operated there. Today, the city is primarily an academic, administrative and service centre. At present, mainly the food industry (for example, a brewery and a pasta factory) is developing there. There are also a few not very large pharmaceutical, agricultural machinery and chemical plants. All of them are concentrated in the eastern part of the city, which means, given the prevailing western winds, that the emissions of industrial pollution do not have too big an impact on the state of the environment in the city. The conducted research indicates a relatively low level of contamination of soils and street dust with trace metals $[32,34,35]$. Currently, no measurements of heavy metal emissions to the atmosphere have been carried out in Lublin.

The sampling points were located within different functional areas of the cityresidential districts, commercial and service centres, and industrial areas. In total, samples from 62 points (Figure 1) located near street intersections were analysed. The study material came from street pavements, along the edges of the roadway. The material was sampled twice, in March 2013 and March 2018 (each time, samples were collected over two days). The sampling method used is common in investigations of this kind [12,36]. The dust was sampled after a five-day period without precipitation. There was no street washing and there were no snow melting episodes within the month prior to sampling. The samples were collected with a plastic brush into plastic bags, then dried at room temperature, and subjected to preliminary sifting through a $1 \mathrm{~mm}$ sieve in order to remove macro debris. The metal content was tested in material with a diameter of less than $63 \mu \mathrm{m}$, which was obtained by sieving the samples through a steel sieve.

The street dust was ground in a zirconia ball mill, and then pressed pellets were prepared from it. Analyses of the total $\mathrm{Cd}, \mathrm{Cr}, \mathrm{Cu}, \mathrm{Ni}, \mathrm{Pb}$ and $\mathrm{Zn}$ content were performed on an X-ray fluorescence spectrometer (Epsilon5 Panalytical). The metal content of each sample was measured three times and the average was given as the final result. The accuracy of the method was verified using reference material NCS DC 73,385 (measurement error ranged from 3 to $5 \%$ ). 


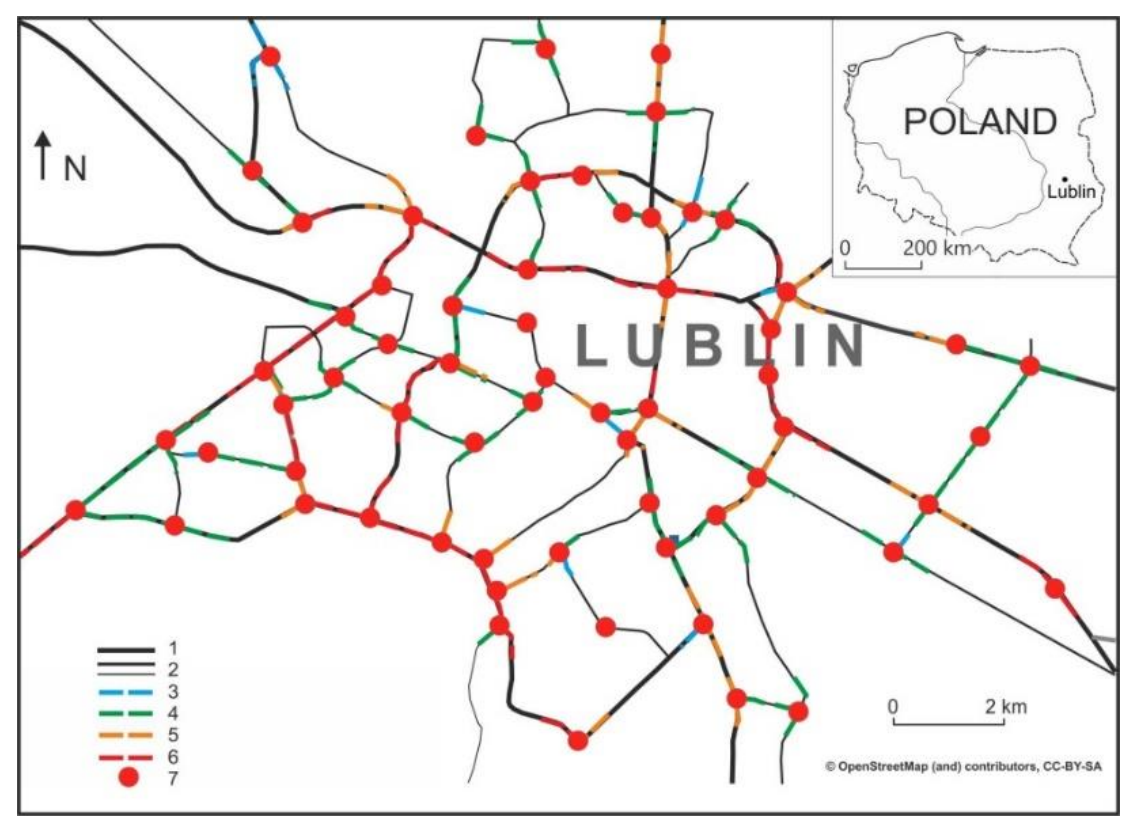

Figure 1. Locations of sampling sites against the background of the Lublin road network (and traffic density): 1 , main roads; 2 , secondary roads; 3, 101-500 cars per hour; 4, 501-1000 cars per hour; 5, 1001-1500 cars per hour; 6,>1500 cars per hour; and 7, sampling sites.

The study used hazard index (HI) and cancer risk (CR) for a quantitative description of health risk related to human exposure to heavy metals contained in street dust [22,23]. The average daily dose quantifies the risk of cancer and non-cancer diseases as a result of human contact with a selected element (in the case studied, it is contact with the solid fraction in the form of street dust). These models are commonly used in studies of the hazard represented by heavy metals in various types of city street dust $[24,26,28,37,38]$. According to the adopted methodology, three methods of contact with the dust hazard and, therefore, three forms of average daily dose (ADD) intake can be distinguished: inhalation described with the parameter $\mathrm{ADD}_{\text {inh }}$ - taking into account, among others, the particle emission factor; skin contact $\left(\mathrm{ADD}_{\text {derm }}\right)$ - taking into account, among others, the skin area exposed to the carcinogen; and ingestion $\left(\mathrm{ADD}_{\text {ing }}\right)$. The equations for these parameters take the following form:

$$
\begin{gathered}
\mathrm{ADD}_{\text {inh }}=\mathrm{C} \times \frac{\mathrm{inhR} \times \mathrm{EF} \times \mathrm{ED}}{\mathrm{PEF} \times \mathrm{BW} \times \mathrm{AT}} \\
\mathrm{ADD}_{\text {derm }}=\mathrm{C} \times \frac{\mathrm{SL} \times \mathrm{SA} \times \mathrm{ABS} \times \mathrm{EF} \times \mathrm{ED}}{\mathrm{BW} \times \mathrm{AT}} \times 10^{-6} \\
\mathrm{ADD}_{\text {ing }}=\mathrm{C} \times \frac{\mathrm{ingR} \times \mathrm{EF} \times \mathrm{ED}}{\mathrm{BW} \times \mathrm{AT}} \times 10^{-6}
\end{gathered}
$$

where $C$ is the concentration of the element, ing $R$ is the age-dependent ingestion rate, inhR is the age-dependent inhalation rate, EF is the frequency of exposure to pollutants, ED is the exposure duration, SA is the skin area exposed to pollutants, $\mathrm{SL}$ is the skin adherence factor, $\mathrm{ABS}$ is the dermal absorption factor, PEF is the particle emission factor, $\mathrm{BW}$ is the average body weight, and AT is the average exposure time (Table 1). 
Table 1. Exposure parameters for the health risk assessment.

\begin{tabular}{cccc}
\hline Parameter & $\begin{array}{c}\text { Value } \\
\text { (Adults) }\end{array}$ & $\begin{array}{c}\text { Value } \\
\text { (Children) }\end{array}$ & Unit \\
\hline ingR [39] & 100 & 200 & $\mathrm{mg}^{3} \mathrm{day}^{-1}$ \\
inhR [40] & 20 & 7.6 & $\mathrm{~m}^{3} \cdot \mathrm{day}^{-1}$ \\
EF [28] & 230 & 230 & $\mathrm{day} \cdot \mathrm{year}$ \\
ED [41] & 24 & 6 & $\mathrm{years}$ \\
SA [41] & 5700 & 2800 & $\mathrm{~cm}^{2}$ \\
SL [28] & 0.07 & 0.2 & $\mathrm{mg} \cdot \mathrm{cm}^{-2} \cdot \mathrm{days}^{-1}$ \\
ABS [28] & 0.001 & 0.001 & - \\
PEF [41] & $1,360,000,000$ & $1,360,000,000$ & $\mathrm{~m}^{3} \cdot \mathrm{kg}^{-1}$ \\
BW [41] & 70 & 15 & $\mathrm{~kg}$ \\
AT1 (for non-carcinogens) [28] & 6360 & 1590 & days \\
AT2 (for carcinogens) [28] & 25,550 & 25,550 & days \\
\hline
\end{tabular}

The hazard index is the sum of the quotients of the three forms of pollutant intake divided by the corresponding element-specific reference doses (Table 2). It is calculated using the following equation:

$$
\mathrm{HI}=\left(\frac{\mathrm{ADDi}}{\mathrm{RfD}}\right)_{\mathrm{ing}}+\left(\frac{\mathrm{ADDi}}{\mathrm{RfD}}\right)_{\mathrm{inh}}+\left(\frac{\mathrm{ADDi}}{\mathrm{RfD}}\right)_{\text {derm }}
$$

where ADDi is the dose of element $i$, and RfD is the reference dose of the element. The proportions in this equation refer to non-carcinogenic effects. The probability of such effects occurring is very low for $\mathrm{HI}<1$, between 1 and 4 the risk of non-carcinogenic effects is possible, for $\mathrm{HI}>4$ the risk is high $[26,28]$.

Table 2. The reference dose and slope factor of metals.

\begin{tabular}{ccccccc}
\hline & $\mathbf{C d}$ & $\mathbf{C r}$ & $\mathbf{C u}$ & $\mathbf{N i}$ & $\mathbf{P b}$ & $\mathbf{Z n}$ \\
\hline $\mathrm{RfD}_{\text {ing }}$ & $0.001^{1}$ & $0.003^{1}$ & $0.04^{1}$ & $0.02^{1}$ & $0.0035^{1}$ & $0.3^{1}$ \\
$\mathrm{RfD}_{\text {inh }}$ & $0.001^{1}$ & $0.0286^{1}$ & $0.042^{1}$ & $0.0206^{1}$ & $0.00352^{1}$ & $0.3^{1}$ \\
$\mathrm{RfD}_{\text {derm }}$ & $0.00001^{1}$ & $0.00006^{1}$ & $0.012^{1}$ & $0.0054^{1}$ & $0.000525^{1}$ & $0.06^{1}$ \\
$\mathrm{SF}_{\text {ing }}$ & $6.1^{2}$ & $0.5^{3}$ & - & $0.91^{3}$ & $0.0085^{3}$ & - \\
$\mathrm{SF}_{\text {inh }}$ & $6.3^{1}$ & $42^{1}$ & - & $0.84^{1}$ & $0.042^{2}$ & - \\
$\mathrm{SF}_{\text {derm }}$ & - & - & - & - & - & - \\
\hline $1-\left[28,^{2}-[42],{ }^{3}-[43]\right.$. & & & & &
\end{tabular}

Lifetime average daily dose (LADD) is represented with equations identical to ADD, only with the parameter AT changed to AL (average life) [43]. For carcinogenic substances, i.e., $\mathrm{As}, \mathrm{Cd}, \mathrm{Cr}, \mathrm{Ni}$, etc., $\mathrm{LADD}$ values are multiplied by an appropriate slope factor (SF), and thus the cancer risk range $(\mathrm{CR})$ is obtained:

$$
\mathrm{CR}=\mathrm{SF} \times \mathrm{LADD}
$$

These results are considered hazardous when cancer risk ranges $(\mathrm{CR})$ are greater than $10^{-6}$ [26] or $10^{-4}$; a definitive lower risk limit is still to be established [24]. In this study, health risk (hazard index and cancer risk) was determined for both adults and children.

Basic descriptive statistics (mean, standard deviation and variation coefficient) of health risk indicators were calculated. $\mathrm{HI}$ and $\mathrm{CR}$ spatial distribution maps were prepared with the Spatial Analyst (QGIS) package through IDW interpolation using the collected data.

\section{Results}

Previously conducted studies indicate that the average heavy metal content in 2018 was lower in the case of $\mathrm{Cd}, \mathrm{Ni}, \mathrm{Pb}$ and $\mathrm{Zn}$, while slightly higher for $\mathrm{Cr}$ and $\mathrm{Cu}$ (Table 3). 
The biggest decrease, by $25 \%$, was observed for $\mathrm{Pb}$, followed by $\mathrm{Ni}$ and $\mathrm{Zn}$ that decreased by about $20 \%$. Similar patterns were found for the maximum values, but the decrease did not occur in the case of $\mathrm{Cr}$ and $\mathrm{Ni}$. The highest enrichment factors in relation to the geochemical background were found for $\mathrm{Zn}$ (7.8-7.2 times), $\mathrm{Cd}$ (7.8-6.8 times) and $\mathrm{Cu}$ (6.4-6.7 times). For the maximum values, the factor reached 19 for $\mathrm{Cu}, 13$ for $\mathrm{Zn}$, and 10 for $\mathrm{Cd}$. The variation coefficient in 2018 was higher for $\mathrm{Cr}$ and $\mathrm{Cu}$, slightly lower for $\mathrm{Cd}$, and basically unchanged for $\mathrm{Ni}, \mathrm{Pb}$ and $\mathrm{Zn}$. For both years studied, it was highest for $\mathrm{Cu}$ and the lowest for $\mathrm{Cd}$ and $\mathrm{Ni}[33]$.

Table 3. Content of heavy metals in street dust $(<63 \mu \mathrm{m})$ in Lublin $\left(\mathrm{mg} \cdot \mathrm{kg}^{-1}\right)$ [31].

\begin{tabular}{ccccccc}
\hline & $\mathbf{C d}$ & $\mathbf{C r}$ & $\mathbf{C u}$ & $\mathbf{N i}$ & $\mathbf{P b}$ & $\mathbf{Z n}$ \\
\hline & & & $\mathbf{2 0 1 3 / 2 0 1 8}$ & & \\
\hline Mean value & $6.3 / 5.5$ & $108.5 / 112$ & $114.9 / 120.6$ & $21.4 / 17.1$ & $62.0 / 46.6$ & $364.4 / 296.2$ \\
Min. value & $4.1 / 4.0$ & $69.8 / 53$ & $43.2 / 26.3$ & $10.9 / 9.1$ & $32.3 / 29.5$ & $127.6 / 99.2$ \\
Max. value & $10.4 / 7.9$ & $153.8 / 274$ & $485.3 / 353$ & $31.9 / 26.9$ & $173.6 / 94.8$ & $618.0 / 587.3$ \\
Standard deviation & $1.5 / 0.9$ & $18.6 / 43.8$ & $60.5 / 82.3$ & $4.2 / 3.6$ & $21.8 / 14.1$ & $117.6 / 103.7$ \\
Variation coefficient (\%) & $23 / 16$ & $17 / 39$ & $52 / 68$ & $19 / 21$ & $35 / 30$ & $32 / 35$ \\
Geochemical background & 0.8 & 60.0 & 17.8 & 12.4 & 21.4 & 41.3 \\
\hline
\end{tabular}

The risk of non-carcinogenic effects appears when HI values are greater than one. In the case of street dust in the Lublin area, even the maximum HI levels for individual elements did not exceed 1/10 of this value, and in most cases (except $\mathrm{Pb}$ in 2013 and Cr in 2018) did not exceed 0.03 of the critical value (Tables 4 and 5). This means that streets dust in the area of Lublin is not hazardous to people and should not pose a risk of non-carcinogenic effects. This applies to indices for both adults and children. In the latter case, the more strict standard is not exceeded $(\mathrm{H}>0.1)$ [42]. There are some differences for individual elements-the index for children is clearly higher in the case of $\mathrm{Pb}$, it is slightly higher for $\mathrm{Cr}$ while in the case other metals, the $\mathrm{HI}$ is lower for children.

Table 4. Hazard Index basic statistics (adults).

\begin{tabular}{|c|c|c|c|c|c|c|}
\hline & $\mathrm{Cd}$ & $\mathrm{Cr}$ & $\mathrm{Cu}$ & $\mathrm{Ni}$ & $\mathbf{P b}$ & $\mathrm{Zn}$ \\
\hline \multicolumn{7}{|c|}{$2013 / 2018$} \\
\hline Mean value & $9.5 \times 10^{-3} / 5.5 \times 10^{-3}$ & $1.3 \times 10^{-2} / 1.5 \times 10^{-2}$ & $3 \times 10^{-3} / 2.2 \times 10^{-3}$ & $0.3 \times 10^{-3} / 0.2 \times 10^{-3}$ & $1.7 \times 10^{-2} / 0.7 \times 10^{-3}$ & $1.1 \times 10^{-3} / 0.9 \times 10^{-3}$ \\
\hline Max. value & $2.4 \times 10^{-2} / 0.8 \times 10^{-2}$ & $1.8 \times 10^{-2} / 3.4 \times 10^{-3}$ & $1.6 \times 10^{-2} / 0.5 \times 10^{-2}$ & $1.5 \times 10^{-2} / 0.3 \times 10^{-3}$ & $4.8 \times 10^{-2} / 1.6 \times 10^{-2}$ & $2.4 \times 10^{-3} / 1.6 \times 10^{-3}$ \\
\hline Standard deviation & $0.3 \times 10^{-2} / 0.1 \times 10^{-2}$ & $0.2 \times 10^{-2} / 0.5 \times 10^{-2}$ & $0.2 \times 10^{-2} / 0.1 \times 10^{-2}$ & $6.2 \times 10^{-5} / 4.9 \times 10^{-5}$ & $0.6 \times 10^{-2} / 0.3 \times 10^{-2}$ & $0.4 \times 10^{-3} / 0.3 \times 10^{-3}$ \\
\hline $\begin{array}{l}\text { Variation coefficient } \\
\qquad(\%)\end{array}$ & $31.9 / 17.3$ & $16.9 / 38.3$ & $77.9 / 55.2$ & $23.0 / 26.6$ & $37.7 / 39.9$ & $36.4 / 38.3$ \\
\hline
\end{tabular}

Table 5. Hazard Index basic statistics (children).

\begin{tabular}{|c|c|c|c|c|c|c|}
\hline & $\mathrm{Cd}$ & $\mathrm{Cr}$ & $\mathrm{Cu}$ & $\mathrm{Ni}$ & $\mathrm{Pb}$ & $\mathrm{Zn}$ \\
\hline \multicolumn{7}{|c|}{$2013 / 2018$} \\
\hline Mean value & $5.0 \times 10^{-3} / 2.9 \times 10^{-3}$ & $2.8 \times 10^{-2} / 3.5 \times 10^{-2}$ & $1.7 \times 10^{-3} / 1.3 \times 10^{-3}$ & $0.6 \times 10^{-3} / 0.4 \times 10^{-3}$ & $9.7 \times 10^{-3} / 4.2 \times 10^{-3}$ & $0.6 \times 10^{-3} / 0.5 \times 10^{-3}$ \\
\hline Max. value & $1.3 \times 10^{-2} / 0.4 \times 10^{-2}$ & $4.8 \times 10^{-2} / 6.5 \times 10^{-2}$ & $9 \times 10^{-3} / 3 \times 10^{-3}$ & $0.9 \times 10^{-3} / 0.8 \times 10^{-3}$ & $2.7 \times 10^{-2} / 0.9 \times 10^{-2}$ & $1 \times 10^{-3} / 1 \times 10^{-3}$ \\
\hline Standard deviation & $1.5 \times 10^{-3} / 0.5 \times 10^{-3}$ & $6 \times 10^{-3} / 8 \times 10^{-3}$ & $1.3 \times 10^{-3} / 0.6 \times 10^{-3}$ & $0.1 \times 10^{-3} / 0.1 \times 10^{-3}$ & $3.5 \times 10^{-3} / 1.6 \times 10^{-3}$ & $0.2 \times 10^{-3} / 0.2 \times 10^{-3}$ \\
\hline $\begin{array}{l}\text { Variation coefficient } \\
(\%)\end{array}$ & $30.8 / 17.6$ & $26.6 / 25.1$ & $73.9 / 51.3$ & $22.8 / 26.9$ & $36.1 / 38.4$ & $35.7 / 41.5$ \\
\hline
\end{tabular}

From 2013 to 2018, changes occurred in both the value and variation of HI distribution for the individual elements in the area of Lublin. For $\mathrm{Ni}, \mathrm{Pb}$ and $\mathrm{Zn}$, changes in the variation of HI distribution (described with VC) were small. The mean HI value in all three cases decreased in 2018 compared to 2013 from about 18\% for $\mathrm{Zn}$ to more than $56 \%$ for Pb. For $\mathrm{Cd}$ and $\mathrm{Cu}$, the mean $\mathrm{HI}$ value also decreased (by $42 \%$ and $27 \%$, respectively), but the variation of HI distribution in 2018 decreased significantly compared to the variation in 2013, which was due to a significant decrease in the maximum HI values. The only increase 
of the HI between 2013 and 2018 (0.0013/0.0015) was observed for Cr, and, at the same time, there was a twofold increase in the variation of $\mathrm{HI}$ distribution within Lublin.

For CR, which is calculated only for carcinogenic elements, the results differ slightly (Tables 6 and 7). When the more strict limit of $10^{-6}$ is adopted for CR values, clear changes can be seen between 2013 and 2018. In 2013, the mean and maximum CR values exceeded $10^{-5}$ for $\mathrm{Cd}$ and $\mathrm{Cr}$, while in 2018 , the CR for these two elements clearly decreased and were almost below the strict limit of $10^{-6}$. Among carcinogenic elements, only the mean and maximum $\mathrm{CR}$ values for $\mathrm{Pb}$ did not exceed the strict critical value of $10^{-6}$ in 2013 and 2018. In the case of $\mathrm{Cd}, \mathrm{Cr}$ and $\mathrm{Ni}$, the mean $\mathrm{CR}$ values were of the order of $10^{-6}$ in 2018 , but they exceeded this limit. For $\mathrm{Cr}$, on the other hand, the CR values were an order of magnitude greater than the mean values. Between 2013 and 2018, the changes in CR were considerably greater than changes in $\mathrm{HI}$. The mean $\mathrm{CR}$ values for $\mathrm{Cd}, \mathrm{Cr}$ and $\mathrm{Pb}$ decreased by nearly an order of magnitude, and in the case of $\mathrm{Ni}$, by $30 \%$. The variation coefficient for $\mathrm{CR}$ increased very slightly for $\mathrm{Ni}$ and $\mathrm{Pb}$, and more than doubled for $\mathrm{Cr}$. However, in the case of $\mathrm{Cd}$ distribution, the variation coefficient for CR was nearly twice as low.

Table 6. Cancer risk basic statistics (adults).

\begin{tabular}{ccccc}
\hline & Cd & $\mathbf{C r}$ & $\mathbf{N i}$ & $\mathbf{P b}$ \\
\hline & & $\mathbf{2 0 1 3 / 2 0 1 8}$ & \\
\hline Mean value & $1.0 \times 10^{-5} / 5.9 \times 10^{-6}$ & $1.7 \times 10^{-5} / 1.9 \times 10^{-6}$ & $4.8 \times 10^{-6} / 3.3 \times 10^{-6}$ & $1.2 \times 10^{-7} / 5.3 \times 10^{-8}$ \\
Max. value & $2.6 \times 10^{-5} / 8.5 \times 10^{-6}$ & $2.4 \times 10^{-5} / 4.2 \times 10^{-5}$ & $6.7 \times 10^{-6} / 6.1 \times 10^{-6}$ & $3.4 \times 10^{-7} / 1.2 \times 10^{-7}$ \\
Standard deviation & $3.2 \times 10^{-6} / 1.0 \times 10^{-6}$ & $2.9 \times 10^{-6} / 7.0 \times 10^{-6}$ & $1.1 \times 10^{-6} / 8.8 \times 10^{-7}$ & $4.5 \times 10^{-8} / 2.1 \times 10^{-8}$ \\
Variation coefficient (\%) & $31.9 / 17.3$ & $16.9 / 38.3$ & $23.0 / 26.6$ & $37.7 / 39.9$ \\
\hline
\end{tabular}

Table 7. Cancer risk basic statistics (children).

\begin{tabular}{ccccc}
\hline & $\mathbf{C d}$ & $\mathbf{C r}$ & $\mathbf{N i}$ & $\mathbf{P b}$ \\
\hline & & $\mathbf{2 0 1 3 / 2 0 1 8}$ & \\
\hline Mean value & $2.8 \times 10^{-4} / 1.6 \times 10^{-4}$ & $3.8 \times 10^{-4} / 5.4 \times 10^{-4}$ & $4.4 \times 10^{-4} / 1.3 \times 10^{-4}$ & $3.3 \times 10^{-6} / 1.4 \times 10^{-6}$ \\
Max. value & $7.2 \times 10^{-4} / 2.3 \times 10^{-4}$ & $7.4 \times 10^{-4} / 1.0 \times 10^{-3}$ & $1.8 \times 10^{-4} / 1.7 \times 10^{-4}$ & $9.3 \times 10^{-6} / 3.2 \times 10^{-6}$ \\
Standard deviation & $8.5 \times 10^{-5} / 2.8 \times 10^{-5}$ & $1 \times 10^{-4} / 1.0 \times 10^{-4}$ & $1.2 \times 10^{-4} / 3.0 \times 10^{-5}$ & $1.2 \times 10^{-6} / 5.5 \times 10^{-7}$ \\
Variation coefficient (\%) & $30.8 / 17.6$ & $26.6 / 25.2$ & $26.9 / 22.8$ & $36.1 / 38.4$ \\
\hline
\end{tabular}

Clearly higher $C R$ values were found in the case of children. For all elements, except $\mathrm{Pb}$, they were of the order of $10^{-4}$, which means that they exceeded the critical values. In 2013, the maximum CR value for Cd was 0.0007. In 2018, it decreased by two thirds, while the mean value remained at 0.0002 . The mean $\mathrm{CR}$ value for $\mathrm{Ni}$ also decreased, but its maximum values in 2013 and 2018 were similar-0.00018 and 0.00017 , respectively. The maximum CR value for $\mathrm{Cr}$ increased considerably from 0.0007 in 2013 to 0.001 in 2018. The mean $C R$ value also increased for $\mathrm{Cr}$.

$\mathrm{Pb}$ was the only element for which $\mathrm{CR}$ values were below the less strict limit of $10^{-4}$ and near the more strict limit of $10^{-6}$. Its mean values were twice as low in 2013 compared to 2018, while the maximum values were four times as low. Therefore, it can be assumed that, unlike the other carcinogenic elements, $\mathrm{Pb}$ is not hazardous to children in Lublin.

The distribution of HI values for all elements changed between 2013 and 2018 (Figure 2). For Cd, both distributions are strongly elongated, right-skewed (Cd: 2013, 0.007-0.01; 2018, 0.0043-0.006), but most data for 2018 are concentrated around the lower value of the modal interval. The right-skewed distribution indicates exceptional higher HI values. The HI distribution in 2013 showed very high values that did not occur in 2018. A clear increase of $\mathrm{HI}$ values can be observed for $\mathrm{Cr}$ in 2018. In 2013, most of the data were contained in the 0.0075-0.014 interval. In 2018, the distribution was more flattened and most of the data were contained in the wide interval of 0.01-0.02. In both cases, the data distribution was elongated, meaning that most of the data were contained near the modal interval with 
the 2013 distribution being more elongated than the 2018 distribution. For $\mathrm{Cu}$, the HI distribution is strongly elongated and right-skewed. In 2013, most values were contained in the 0.00048-0.0037 interval, but a small peak for large values (i.e., above 0.015) was visible. In 2018, most values were in the $0.001-0.0039$ interval, and sites with high $\mathrm{HI}$ values did not appear. In 2013, the distribution for Ni was more flattened, with most HI values within the 0.00019-0.000366 interval, and in 2018 the distribution was more elongated, with most $\mathrm{HI}$ values in the lower 0.00011-0.000256 interval. At the same time, the kurtosis of the distribution in 2013 was similar to the kurtosis of normal distribution, but the distribution for $\mathrm{Ni}$ was left-skewed (i.e., had a surplus of data with high values), while that in 2018 was right-skewed and elongated. This means that most data were contained in the narrower interval with lower values. In the case of the $\mathrm{HI}$ for $\mathrm{Pb}$, the kurtosis of distribution in 2013 was significantly higher, while in 2018 it was slightly higher than the kurtosis of normal distribution. The modal interval shifted to lower values in 2018. Most of the data were between 0.011-0.02 in 2013 and between 0.0036-0.09 in 2018. At the same time, there were no high (0.04-0.05) $\mathrm{HI}$ values for $\mathrm{Pb}$ in 2018. For $\mathrm{Zn}$, both distributions were slightly elongated and statistically symmetrical. However, the distribution for 2018 was more elongated (more compact). In 2013, most of the data were between 0.00055 and 0.00155 , and in 2018 between 0.0003 and 0.00138 . The $\mathrm{HI}$ distribution for the three elements- $\mathrm{Cu}, \mathrm{Cd}$ and $\mathrm{Pb}$-shows a clear change between 2013 and 2018. There was an absence of the highest values (extremely high compared to the other values) deviating from the modal values.
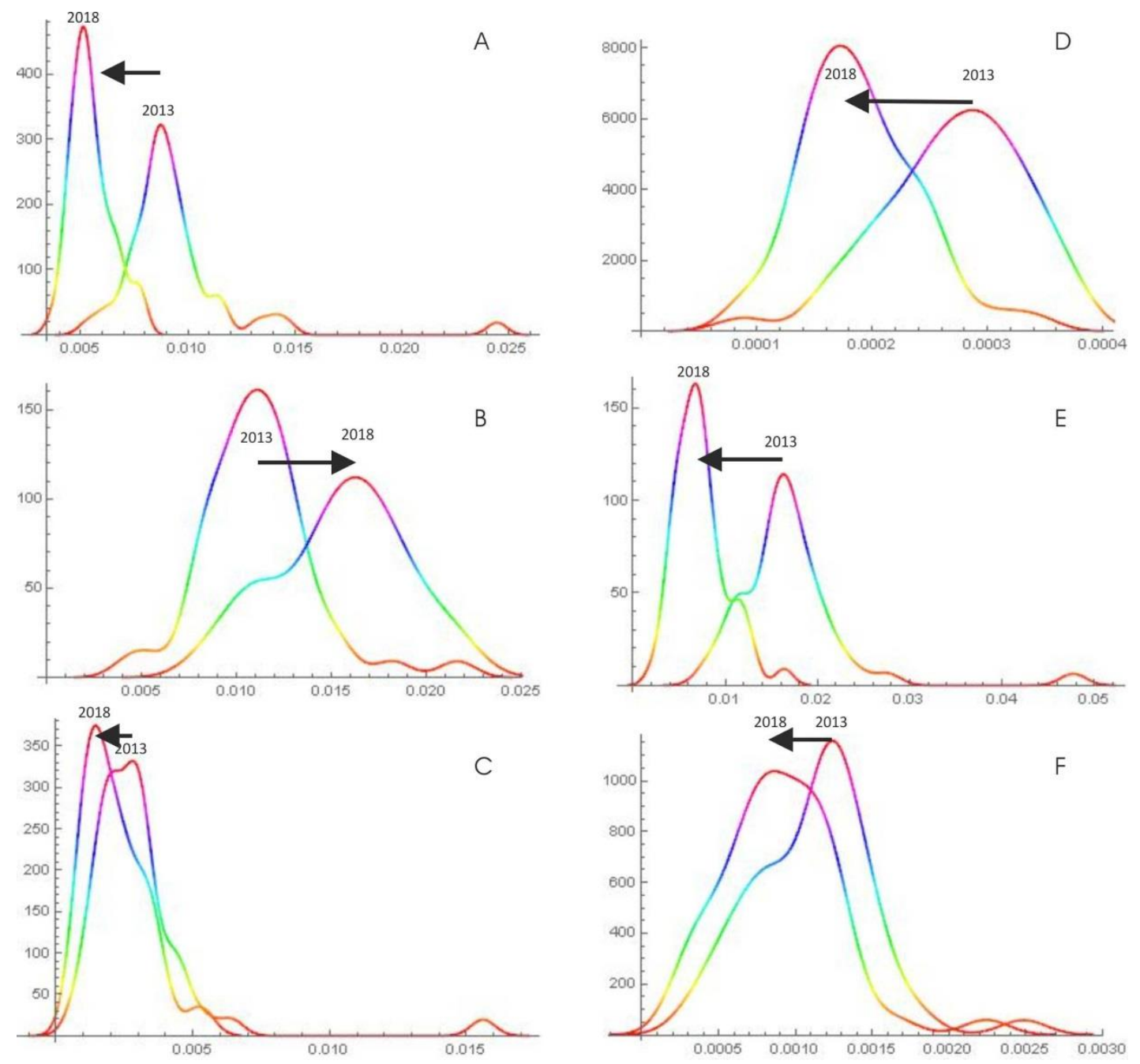

Figure 2. Distribution of $\mathrm{HI}$ data for $\mathrm{Cd}(\mathbf{A}), \mathrm{Cr}(\mathbf{B}), \mathrm{Cu}(\mathbf{C}), \mathrm{Ni}(\mathbf{D}), \mathrm{Pb}(\mathbf{E})$, and $\mathrm{Zn}(\mathbf{F})$. The direction of the arrow shows the direction of the change from 2013 to 2018. 
Analysis of the spatial variation of $\mathrm{HI}$ and $\mathrm{CR}$ values for the individual metals shows clear changes (Figures 3 and 4). In 2013, HI reached the highest values for $\mathrm{Cd}$ in the south-western part of Lublin. In 2018, there was a very distinct decrease of this index in the entire area of the city. The lowest values occurred in the northern and SE part of the city. In the case of $\mathrm{Cr}$, there was a mosaic-like pattern of areas with different $\mathrm{HI}$ values, and the spatial variation was distinctly greater in 2018. In 2013, there was an area with higher values of the index for $\mathrm{Cu}$ in the SW part of Lublin, but the same was not observed in 2018. The indices for $\mathrm{Ni}$ in 2013 were the highest in the western and eastern part of the city. In 2018 , slightly higher values were found in just a few locations. In the case of $\mathrm{Pb}$ in 2013, the highest HI values occurred in the eastern part of the city. In 2018, a very distinct decrease was observed for this index, and the lowest values were found in the central part of the city. The distribution of the index for $\mathrm{Zn}$ was very similar to its distribution for $\mathrm{Cu}$ (Figure 3).
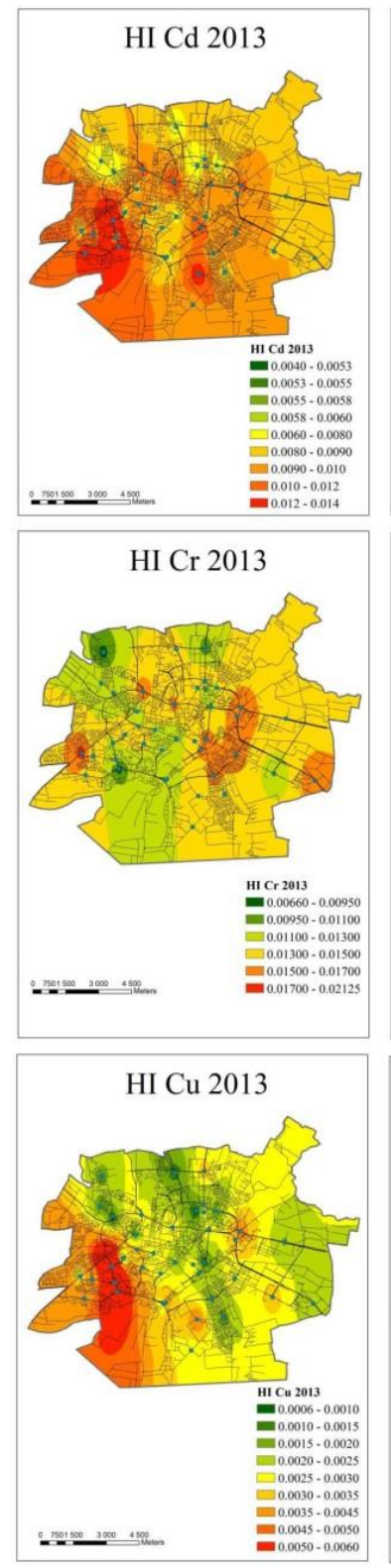
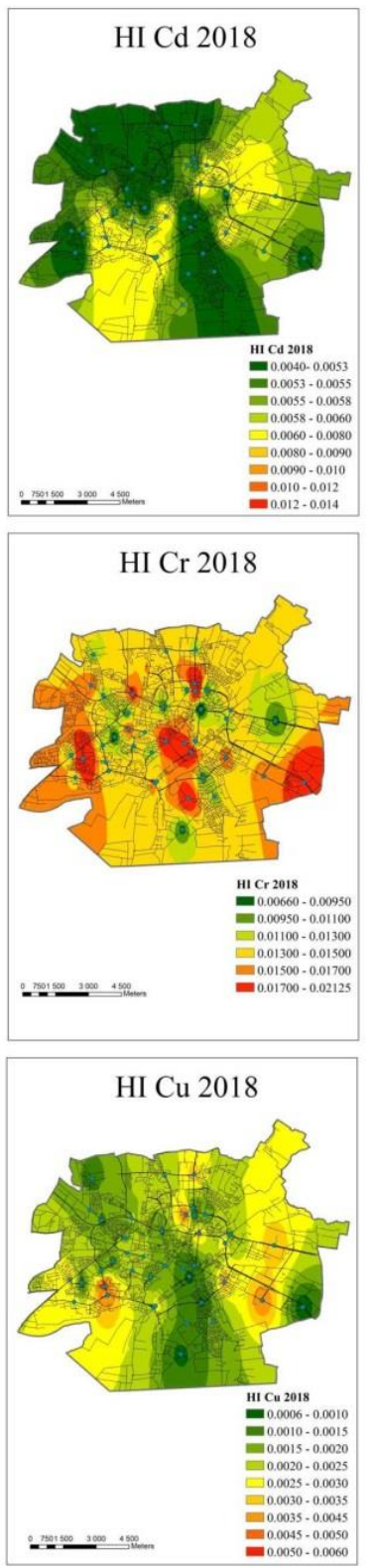
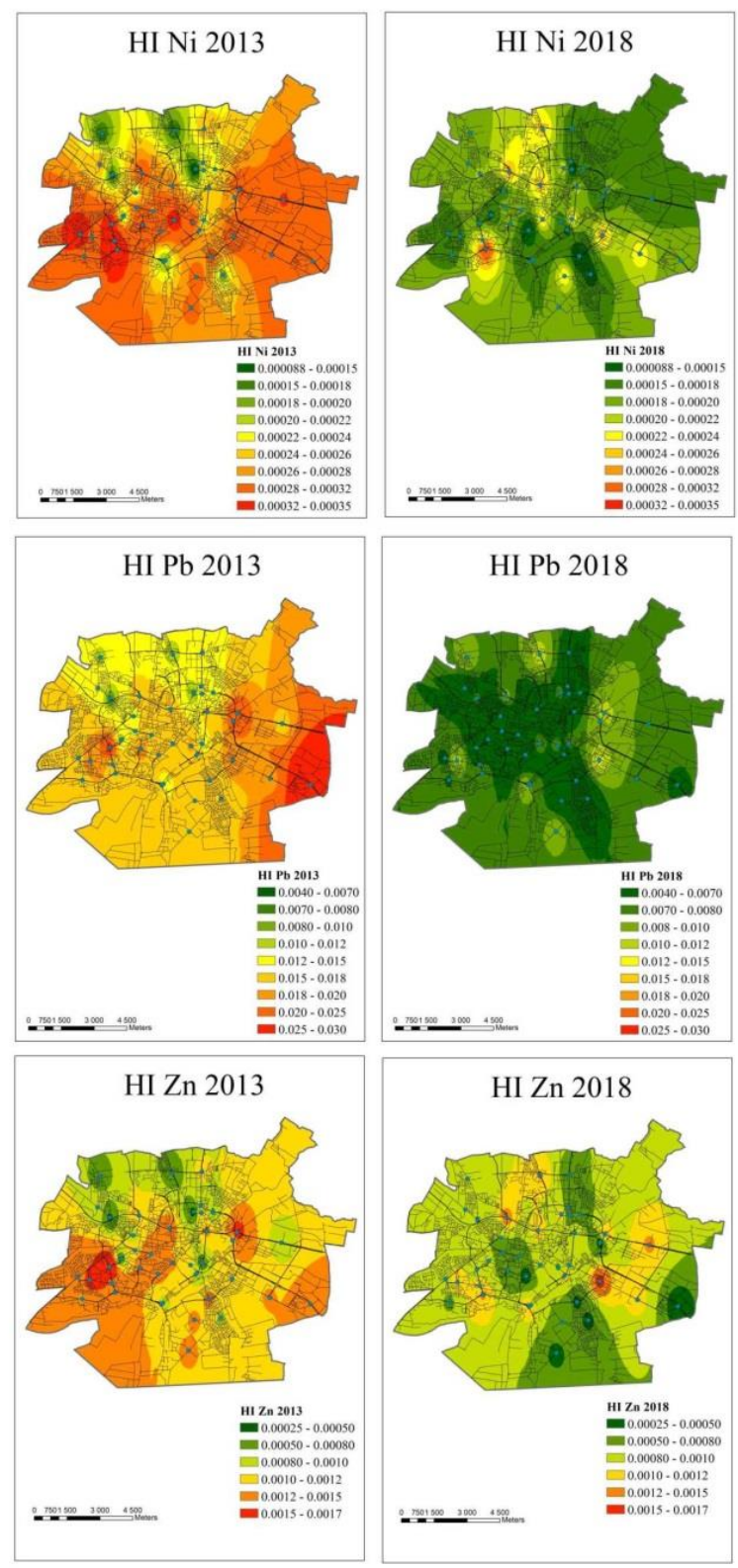

Figure 3. Spatial distribution of HI (for adults) in 2013 and 2018. 

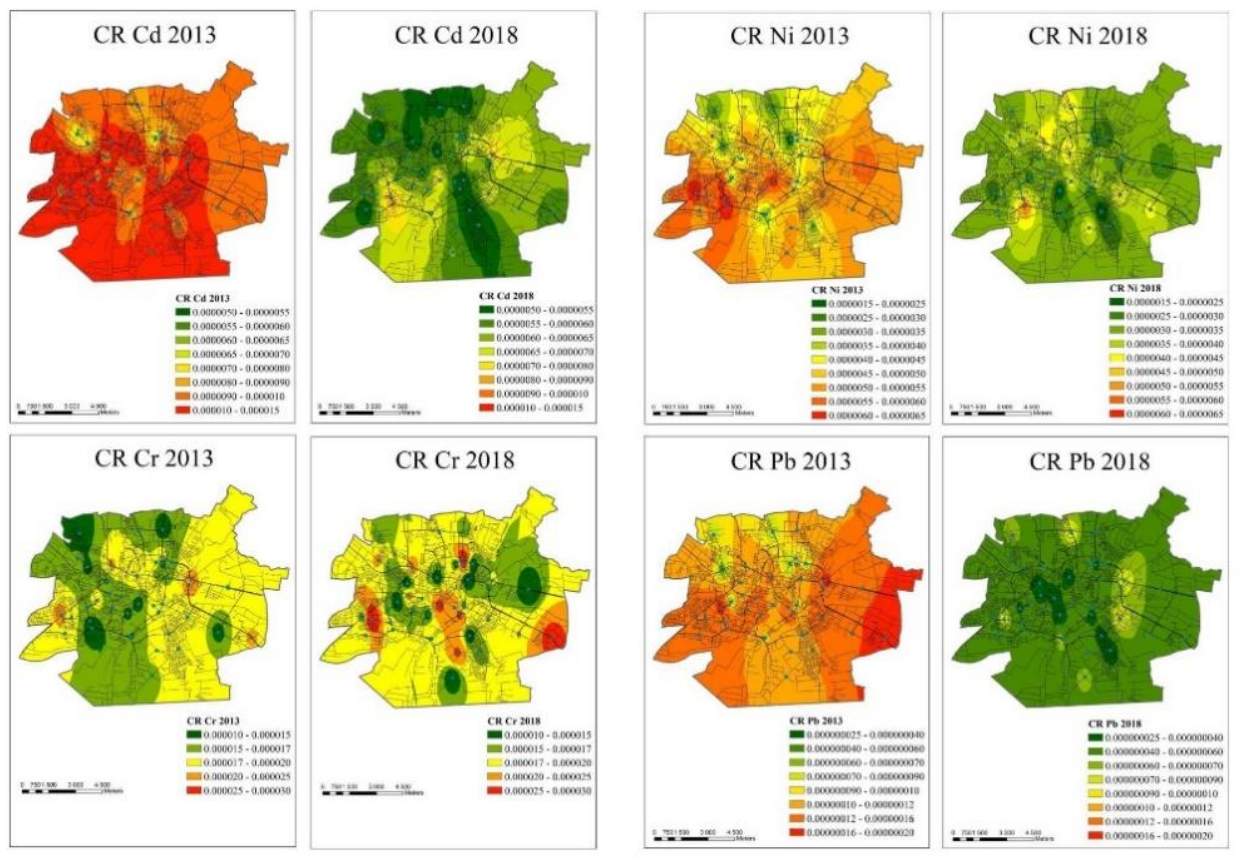

Figure 4. Spatial distribution of the CR index (for adults) within Lublin in 2013 and 2018.

In 2013, the highest CR values for adults in the case of Cd occurred in the southern, western and central part of the city (Figure 4). In 2018, areas with slightly higher values of the index were found only in the SW part, but these values were clearly lower than in 2013. CR values for cadmium exceeding the stricter limit of $10^{-6}$ encompassed the entire area of the city in 2013 and 2018 alike. However, these values did not exceed the limit of $10^{-4}$ in any location. CR distribution for $\mathrm{Cr}$ in 2013 showed slightly higher values in the western part of the city. In 2018, the distribution was entirely different-there were a few locations with clearly higher values of the index, mainly in the central part of the city. The maximum $\mathrm{CR}$ values for $\mathrm{Cr}$, marked with red, are of the order of $3 \times 10^{-5}$. In the case of $\mathrm{Ni}$, the highest CR values were recorded in 2013 in the western part of Lublin, while in 2018 nearly all of these anomalies disappeared. The maximum CR values for $\mathrm{Ni}$ were of the order of $10^{-6}$. For $\mathrm{Pb}$, the highest values in 2013 occurred in the eastern and south-western part of the city. Similarly to $\mathrm{Ni}$, the situation in 2018 changed and CR reached clearly lower values all over the city (Figure 4). Despite the variation, $\mathrm{CR}$ values for $\mathrm{Pb}$ did not exceed the limit of $10^{-6}$ anywhere in Lublin.

\section{Discussion}

Although for some heavy metals in street dust, the concentrations found in 2013 and 2018 were several times above the level of the geochemical background, the risk of non-cancer health effects was very low. The HI values for maximum and average values were usually around 0.01 (Table 8). In the case of adults, HI reached the highest values for $\mathrm{Pb}$ (2013), $4.8 \times 10^{-2} ; \mathrm{Cr}$ (2018), $3.4 \times 10^{-2}$; and $\mathrm{Cd}(2013), 2.8 \times 10^{-2}$. The situation was different in the case of CR where the greatest hazard to adults in 2013/2018, respectively, was represented by $\mathrm{Cd}\left(2.6 \times 10^{-5} / 8.5 \times 10^{-6}\right)$ and $\mathrm{Cr}\left(2.4 \times 10^{-5} / 4.2 \times 10^{-5}\right)$. The hazard associated with both elements was greater in 2013. The same elements posed a hazard to children, but the $\mathrm{CR}$ values for children were 10 or 100 times higher than for adults $(2013 / 2018)-\operatorname{Cd} 2.8 \times 10^{-4} / 1.6 \times 10^{-4}$ and $\mathrm{Cr}\left(3.8 \times 10^{-4} / 5.4 \times 10^{-4}\right)$. An additional risk associated with Ni occurred $(2013 / 2018)-4.4 \times 10^{-4} / 1.3 \times 10^{-4}$. Among carcinogenic elements, only $\mathrm{Pb}$ concentrations did not pose a health risk (Table 9). 
Table 8. Comparison of hazard indices for Kraków, Wrocław and Lublin.

\begin{tabular}{|c|c|c|c|c|}
\hline & $\mathrm{Cr}$ & $\mathrm{Cu}$ & $\mathrm{Ni}$ & Zn \\
\hline Children $^{1}$ & $6.1 \times 10^{-2}-3.4 \times 10^{-1}$ & $2.7 \times 10^{-3}-3.7 \times 10^{-2}$ & $3.3 \times 10^{-3}-1.1 \times 10^{-2}$ & $5.3 \times 10^{-3}-1 \times 10^{-1}$ \\
\hline Children $^{2}$ & $5.5 \times 10^{-2}-2.9 \times 10^{-1}$ & $3.1 \times 10^{-3}-3.9 \times 10^{-2}$ & $5.9 \times 10^{-2}-2 \times 10^{-2}$ & $9.5 \times 10^{-4}-2.6 \times 10^{-3}$ \\
\hline Children—this study (mean) $(2013 / 2018)$ & $2.8 \times 10^{-2} / 3.5 \times 10^{-2}$ & $1.7 \times 10^{-3} / 1.3 \times 10^{-3}$ & $0.6 \times 10^{-3} / 0.4 \times 10^{-3}$ & $0.6 \times 10^{-3} / 0.5 \times 10^{-3}$ \\
\hline Children — this study (maximum) $(2013 / 2018)$ & $4.8 \times 10^{-2} / 6.5 \times 10^{-2}$ & $9 \times 10^{-3} / 3 \times 10^{-3}$ & $0.9 \times 10^{-3} / 0.8 \times 10^{-3}$ & $1 \times 10^{-3} / 1 \times 10^{-3}$ \\
\hline Adults ${ }^{1}$ & $4 \times 10^{-2}-2.3 \times 10^{-1}$ & $5 \times 10^{-4}-1.7 \times 10^{-2}$ & $2 \times 10^{-3}-7.2 \times 10^{-3}$ & $2.4 \times 10^{-3}-4.9 \times 10^{-2}$ \\
\hline Adults ${ }^{2}$ & $3.7 \times 10^{-2}-1.9 \times 10^{-1}$ & $1.4 \times 10^{-3}-1.8 \times 10^{-2}$ & $3.6 \times 10^{-3}-1.2 \times 10^{-2}$ & $4.3 \times 10^{-4}-1.2 \times 10^{-3}$ \\
\hline Adults—this study (mean) $(2013 / 2018)$ & $1.3 \times 10^{-2} / 1.5 \times 10^{-2}$ & $3 \times 10^{-3} / 2.2 \times 10^{-3}$ & $0.3 \times 10^{-3} / 0.2 \times 10^{-3}$ & $1.1 \times 10^{-3} / 0.9 \times 10^{-3}$ \\
\hline Adults-this study (maximum) $(2013 / 2018)$ & $1.8 \times 10^{-2} / 3.4 \times 10^{-3}$ & $1.6 \times 10^{-2} / 0.5 \times 10^{-2}$ & $1.5 \times 10^{-2} / 0.3 \times 10^{-3}$ & $2.4 \times 10^{-3} / 1.6 \times 10^{-3}$ \\
\hline
\end{tabular}

Table 9. Comparison of cancer risk indices for Kraków, Wrocław and Lublin.

\begin{tabular}{|c|c|c|}
\hline & $\mathrm{Cr}$ & $\mathrm{Ni}$ \\
\hline Children $^{1}$ & $1.3 \times 10^{-8}-1.5 \times 10^{-7}$ & $5.2 \times 10^{-10}-1.1 \times 10^{-9}$ \\
\hline Children ${ }^{2}$ & $8.9 \times 10^{-9}-7 \times 10^{-8}$ & $4.1 \times 10^{-10}-1.2 \times 10^{-9}$ \\
\hline Children-this study (mean) $(2013 / 2018)$ & $3.8 \times 10^{-4} / 5.4 \times 10^{-4}$ & $4.4 \times 10^{-4} / 1.3 \times 10^{-4}$ \\
\hline Children-this study (maximum) $(2013 / 2018)$ & $7.4 \times 10^{-4} / 1.0 \times 10^{-3}$ & $1.8 \times 10^{-4} / 1.7 \times 10^{-4}$ \\
\hline Adults ${ }^{1}$ & $6 \times 10^{-8}-6.7 \times 10^{-7}$ & $2.2 \times 10^{-9}-4.8 \times 10^{-9}$ \\
\hline Adults ${ }^{2}$ & $3.9 \times 10^{-8}-3 \times 10^{-7}$ & $1.8 \times 10^{-9}-5.1 \times 10^{-9}$ \\
\hline Adults-this study (mean) $(2013 / 2018)$ & $1.72 \times 10^{-5} / 1.9 \times 10^{-6}$ & $4.85 \times 10^{-6} / 3.36 \times 10^{-6}$ \\
\hline Adults-this study (maximum) $(2013 / 2018)$ & $2.4 \times 10^{-5} / 4.29 \times 10^{-5}$ & $6.72 \times 10^{-6} / 6.09 \times 10^{-6}$ \\
\hline
\end{tabular}

${ }^{1}$ : Katowice, ${ }^{2}$ : Wrocław [29].

Zgłobicki et al. (2019) [33] found that concentrations of heavy metals (except Cd) in street dust in Lublin were distinctly lower compared to other cities in Europe. There was a decrease in the level of contamination of street dust with heavy metals, also observed by other researchers [44-46], with the exception of Cr whose content increased slightly. The tendency for the contamination to increase occurred in other cities even though this is a sporadic phenomenon in Europe. A direct comparison of the health threat determined in this study with the results of studies conducted in other cities is difficult due to differences in the methods used to assess the concentration of metals, the size of the fraction in which the concentration was determined, or the rules adopted for the calculation of indices (exposure duration, body weight, ways of exposure to pollution, etc.). Therefore, the intensity of the threat was compared with two cities in Poland where such studies had been carried out previously.

In the case of HI, the determined risk is similarly low as for Wrocław and Kraków [29], but it should be emphasized that these two cities are definitely larger (Table 8). A comparison of $C R$ indices for these cities with the data obtained for Lublin indicates a clearly higher risk in the latter city (Table 9). This is related to the fact that only inhalation was taken into account by Rybak et al. (2020) [29] as a route by which heavy metals enter the human body. On the other hand, studies conducted by Traczyk and Gruszecka-Kosowska (2020) [44] took into account all three routes (inhalation, skin contact, and ingestion) and indicated that the total non-carcinogenic risk indices $(\mathrm{HI}>1)$ and total carcinogenic risk indices $\left(1.6-1.7 \times 10^{-4}\right)$ were exceeded for both adults and children.

Previous studies indicated that anthropogenic supply is the main source of elements such as Cd, Cu and $\mathrm{Zn}$ [30]. No influence of road traffic intensity in Lublin on the level of the local distribution of pollutants and related health threat was found. The highest spatial variation of indicators occurred in 2013 and concerned elements such as $\mathrm{Cr}, \mathrm{Cu}$ and $\mathrm{Zn}$. The lack of correlation between traffic intensity and the size of the health threat may result from the supply of combustion products coming from sources other than traffic to street dust $[1,12]$. In the case of Lublin, the combustion of coal in private houses can be the source of pollution. The lack of links between the volume of road traffic and the level of pollution has been reported by other authors [47,48]. Another reason for the lack of correlation with traffic intensity may be the displacement of road pollutants by winds, which blow at an average speed of $2.75 \mathrm{~m} / \mathrm{s}$ in Lublin [49]. The diversity of the speed and intensity of winds in the city may also be related to the tunnel effects and local differences in surface heating. 
The conducted research has a practical application. It enables assessment of the spatial differentiation of health risk in the city. This, in turn, allows for appropriate spatial planning management on the city scale-for example, designating recreational areas for residents, in particular, playgrounds. Knowledge of the general layout of areas with high heavy metal concentrations can also be used when planning new housing developments. It can also be helpful in activities aimed at limiting the negative health effects of pollution of the urban environment. The collected information is particularly valuable because no monitoring studies are carried out on the content of heavy metals in soils, air and city waters.

Future research should focus on a better understanding of the determinants of heavy metal content in road dust in medium-sized cities, as well as an accurate assessment of their concentration in all environmental components-air, soil and road dust.

\section{Conclusions}

Dust accumulating on street surfaces within Lublin contains increased heavy metal concentrations. There is a significant spatial variation of concentration within the territory of the city. However, heavy metals do not pose a health threat associated with noncarcinogenic effects on adults and children. The situation is different with regard to the threat posed by carcinogenic elements-it affects both adults and children, the latter in particular. For $\mathrm{Cd}, \mathrm{Cr}$ and $\mathrm{Ni}$, the mean and maximum values exceed the less strict standards $\left(>10^{-4}\right)$. Paradoxically, the lowest health risk in Lublin is associated with the presence of lead which, for a long time, had been treated as the most dangerous element associated with motor vehicle transport. Within a five-year period (2013-2018), there was a significant decrease in the health threat posed by heavy metals contained in street dust. In the case of carcinogenic elements, however, the risk did not disappear completely.

Author Contributions: Conceptualization, W.Z.; methodology, W.Z. and M.T.; investigation, W.Z. and M.T.; writing — original draft preparation, W.Z. and M.T.; writing—review and editing, W.Z. and M.T.; visualization, W.Z. and M.T. All authors have read and agreed to the published version of the manuscript.

Funding: This research received no external funding.

Institutional Review Board Statement: Not applicable.

Informed Consent Statement: Not applicable.

Acknowledgments: We acknowledge Aneta Pasierbińska and Sebastian Skupiński for the help with sample collection and geochemical analysis. The authors wish to thank the editor and anonymous reviewers for their valuable comments and suggestions to improve the quality of this paper.

Conflicts of Interest: The authors declare no conflict of interest.

\section{References}

1. Bilos, C.; Colombo, J.C.; Skorupka, C.N.; Presa, M.J.R. Sources, distribution and variability of airborne trace metals in La Plata City area, Argentina. Environ. Pollut. 2001, 111, 149-158. [CrossRef]

2. Ordóñez, A.; Loredo, J.; De Miguel, E.; Charlesworth, S. Distribution of heavy metals in street dust and soil of an industrial city in Northern Spain. Arch. Environ. Contam. Toxicol. 2003, 44, 160-170. [CrossRef] [PubMed]

3. Manno, E.; Varrica, D.; Dongarrà, G. Metal distribution in road dust samples collected in an urban area close to a petrochemical plant at Gela, Sicily. Atmos. Environ. 2006, 40, 5929-5941. [CrossRef]

4. Wong, C.S.C.; Li, X.; Thornton, I. Urban environmental geochemistry of trace metals. Environ. Pollut. 2006, 142, 1-16. [CrossRef] [PubMed]

5. Amato, F.; Pandolfi, M.; Moreno, T.; Furger, M.; Pey, J.; Alastuey, A.; Bukowiecki, N.; Prevot, A.S.H.; Baltensperger, U.; Querol, X. Sources and variability of inhalable street dust particles in three European cities. Atmos. Environ. 2011, 45, 6777-6787. [CrossRef]

6. Charlesworth, S.; De Miguel, E.; Ordóñez, A. A review of the distribution of particulate trace elements in urban terrestrial environments and its application to consideration of risk. Environ. Geochem. Health 2011, 33, 103-123. [CrossRef] [PubMed]

7. Angelone, M.; Armiento, G.; Cinti, D.; Somma, R.; Trocciola, A. Platinum and heavy metal concentration levels in urban soils of Naples (Italy). Fresenius Environ. Bull. 2002, 11, 1-5.

8. Lu, X.; Wang, L.; Li, L.Y.; Lei, K.; Huang, L.; Kang, D. Multivariate statistical analysis of heavy metals in street dust of Baoji, NW China. J. Hazard. Mater. 2010, 173, 744-749. [CrossRef] 
9. Al-Khashman, O.A. Heavy metal distribution in dust, street dust and soils from the work place in Karak Industrial Estate, Jordan. Atmos. Environ. 2004, 38, 6803-6812. [CrossRef]

10. Sezgin, N.; Ozcan, H.K.; Demir, G.; Nemlioglu, S.; Bayat, C. Determination of heavy metal concentration in street dusts in Istanbul E-5 highway. Environ. Int. 2003, 29, 979-985. [CrossRef]

11. Ahmed, F.; Ishiga, H. Trace metal concentrations in street dusts of Dhaka city, Bangladesh. Atmos. Environ. 2006, 40, 3835-3844. [CrossRef]

12. Han, Y.M.; Du, P.X.; Cao, J.J.; Posmentier, E.S. Multivariate analysis of heavy metal contamination in urban dusts of Xi'an, Central China. Sci. Total Environ. 2006, 355, 176-186.

13. Al-Khashman, O.A. Determination of metal accumulation in deposited street dusts in Amman, Jordan. Environ. Geochem. Health 2007, 29, 1-10. [CrossRef] [PubMed]

14. Shi, X.; Wang, J. Comparison of different methods for assessing heavy metal contamination in street dust of Xianyang City, NW China. Environ. Earth Sci. 2013, 68, 2409-2415. [CrossRef]

15. Du, Y.; Gao, B.; Zhou, H.; Ju, X.; Hao, H.; Yin, S. Health risk assessment of heavy metals in street dusts in urban parks of Beijing, China. Procedia Environ. Sci. 2013, 18, 299-309. [CrossRef]

16. Li, X.; Liu, P.S. Heavy metal contamination of urban soils and street dusts in Hong Kong. Appl. Geochem. 2001, 16, 1361-1368. [CrossRef]

17. Zhao, N.; Lu, X.; Chao, S. Multivariate statistical analysis of heavy metals in less than $100 \mu \mathrm{m}$ particles of street dust from Xining, China. Environ. Earth Sci. 2015, 73, 2319-2327. [CrossRef]

18. Tarzia, M.; de Vivo, B.; Somma, R.; Ayuso, R.A.; McGill, R.A.R.; Parrish, R.R. Anthropogenic vs. natural pollution; an environmental study of an industrial site under remediation (Naples, Italy). Geochem. Explor. Environ. Anal. 2001, 2 Pt 1, 45-56. [CrossRef]

19. Aelion, C.M.; Davis, H.T.; McDermott, S.; Lawson, A.B. Metal concentrations in rural topsoil in South Carolina: Potential for human health impact. Sci. Total Environ. 2008, 402, 149-156. [CrossRef] [PubMed]

20. Zheng, N.; Liu, J.; Wang, Q.; Liang, Z. Health risk assessment of heavy metal exposure to street dust in the zinc smelting district, northeast of China. Sci. Total Environ. 2010, 408, 726-733. [CrossRef]

21. Gope, M.; Masto, R.E.; George, J.; Hoque, R.R.; Balachandran, S. Bioavailability and health risk of some potentially toxic elements $(\mathrm{Cd}, \mathrm{Cu}, \mathrm{Pb}$ and $\mathrm{Zn}$ ) in street dust of Asansol, India. Ecotox. Environ. Safe. 2017, 138, 231-241. [CrossRef] [PubMed]

22. US Environmental Protection Agency. Integrated Risk Information System (IRIS); US Environmental Protection Agency: Washington, DC, USA, 2005.

23. US Environmental Protection Agency. Exposure Factors Handbook, final ed.; US Environmental Protection Agency: Washington, DC, USA, 2011; [EPA/600/R-09/052F].

24. Jiang, Y.; Chao, S.; Liu, J.; Yang, Y.; Chen, Y.; Zhang, A.; Cao, H. Source apportionment and health risk assessment of heavy metals in soil for a township in Jiangsu Province, China. Chemosphere 2017, 168, 1658-1668. [CrossRef] [PubMed]

25. Li, N.; Han, W.; Tang, J.; Bian, J.; Sun, S.; Song, T. Pollution Characteristics and Human Health Risks of Elements in Road Dust in Changchun, China. Int. J. Environ. Res. Public Health 2018, 15, 1843. [CrossRef] [PubMed]

26. Pawełczyk, A.; Božek, F.; Zuber, M. Environmental Risk Case Studies; Czech-Pol Trade: Prague, Czech Republic, 2018.

27. Moryani, H.T.; Kong, S.; Du, J.; Bao, J. Health Risk Assessment of Heavy Metals Accumulated on PM 2.5 Fractioned Road Dust from Two Cities of Pakistan. Int. J. Environ. Res. Public Health 2020, 17, 7124. [CrossRef]

28. Rahman, M.S.; Khan, M.D.H.; Jolly, Y.N.; Kabir, J.; Akter, S.; Salam, A. Assessing risk to human health for heavy metal contamination through street dust in the Southeast Asian Megacity: Dhaka, Bangladesh. Sci. Total Environ. 2019, 660, 1610-1622. [CrossRef]

29. Rybak, J.; Wróbel, M.; Stefan Bihałowicz, J.; Rogula-Kozłowska, W. Selected Metals in Urban Road Dust: Upper and Lower Silesia Case Study. Atmosphere 2020, 11, 290. [CrossRef]

30. De Miguel, E.; Llamas, J.F.; Chacon, E.; Berg, T.; Larsen, S.; Royset, O.; Vadset, M. Origin and patterns of distribution of trace elements in street dust: Unleadedpetrol and urban lead. Atmosph. Environ. 1997, 31, 2733-2740. [CrossRef]

31. Kabata-Pendias, A.; Pendias, H. Biogeochemia Pierwiastków Śladowych; Wydawnictwo Naukowe PWN: Warszawa, Poland, 1999. (In Polish)

32. Zgłobicki, W.; Telecka, M.; Skupiński, S.; Pasierbińska, A.; Kozieł, M. Assessment of heavy metals contamination levels of the street dust in the city of Lublin. Environ. Earth Sci. 2018, 77, 774. [CrossRef]

33. Zgłobicki, W.; Telecka, M.; Skupiński, S. Assessment of short-term changes in street dust pollution with heavy metals in Lublin (E Poland)-levels, sources and risks. Environ. Sci. Poll. Res. 2019, 26, 35049-35060. [CrossRef] [PubMed]

34. Pasieczna, A. Atlas Zanieczyszczeń Gleb Miejskich W Polsce; Państwowy Instytut Geologiczny: Warszawa, Poland, 2003. (In Polish)

35. Plak, A.; Bartmiński, P.; Dębicki, R. Wpływ transportu publicznego na zawartość wybranych metali ciężkich w glebach sąsiadujacych z ulicami Lublina. Proc. Ecopole. 2010, 4, 167-171. (In Polish)

36. Lanzerstorfer, C. Heavy metals in the finest size fractions of road-deposited sediments. Environ. Pollut. 2018, $239,522-531$. [CrossRef] [PubMed]

37. Kicińska, A. Health risk assessment related to an effect of sample size fractions: Methodological remarks. Stoch. Environ. Res. Risk Assess. 2018, 32, 1867-1887. [CrossRef] 
38. Kicińska, A.; Mamak, M.; Skrzypek, M. Heavy metals in sands of sandboxes: Health risk associated with their quantities and form of occurrence in some spas of Poland. Environ. Sci. Pollut. Res. 2017, 24, 19733-19748. [CrossRef] [PubMed]

39. US Environmental Protection Agency. Supplemental Guidance for Developing Soil Screening Levels for Superfund Sites; OSWER 9355.4-24; US Environmental Protection Agency, Office of Solid Waste and Emergency Response: Washington, DC, USA, 2001.

40. Van den Berg, R. Human Exposure to Soil Contamination: A Qualitative and Quantitative Analysis towards Proposals for Human Taxicological Intervention Values; RIVM Report No. 725201011; National Institute of Public Health and Environmental Protection (RIVM): Bilthoven, The Netherlands, 1995.

41. Guidelines for Exposure Assessment; Federal Register 57(104):22888-22938; Risk Assessment Forum U.S. Environmental Protection Agency: Washington, DC, USA, 1992.

42. Bello, S.; Muhammad, B.G.; Bature, B. Total Excess Lifetime Cancer Risk Estimation from Enhanced Heavy Metals Concentrations Resulting from Tailings in Katsina Steel Rolling Mill, Nigeria. J. Mater. Sci. Eng. 2007, 6. [CrossRef]

43. Samuel, U.C.; Nmaduka, N.J.; Ekene, J. Human Health probabilistic Risk Assessment of Achatina achatina (African Giant Snail) consumption as models of mining Activities. Int. J. Sci. Eng. Res. 2018, 9, 1124-1133.

44. Traczyk, P.; Gruszecka-Kosowska, A. The Condition of Air Pollution in Kraków, Poland, in 2005-2020, with Health Risk Assessment. Int. J. Environ. Res. Public Health 2020, 17, 6063. [CrossRef] [PubMed]

45. Pacyna, J.M.; Pacyna, E.G.; Wenche, A. Changes of emissions and atmospheric deposition of mercury, lead, and cadmium. Atmos. Environ. 2009, 43, 117-127. [CrossRef]

46. Harmens, H.; Norris, D.; Mills, G. Heavy Metals and Nitrogen in Mosses: Spatial Patterns in 2010/2011 and Long-Term Temporal Trends in Europe; Centre for Ecology \& Hydrology: Bangor, UK, 2013.

47. Ewen, C.; Anagnostopoulou, M.A.; Ward, N.I. Monitoring of heavy metal levels in roadside dusts of Thessaloniki, Greece in relation to motor vehicle traffic density and flow. Environ. Monit. Assess. 2009, 157, 483-498. [CrossRef]

48. Ordóñez, A.; Álvarez, R.; De Miguel, E.; Charlesworth, S. Spatial and temporal variations of trace element distribution in soils and street dust of an industrial town in NW Spain: 15 years of study. Sci. Total Environ. 2015, 524-525, 93-103. [CrossRef]

49. Kaszewski, B.M. Warunki klimatyczne Lubelszczyzny; Wydawnictwo UMCS: Lublin, Poland, 2008. (In Polish) 